\title{
Integration of Emotional Intelligence: Effectiveness of Cooperative-based Mathematics Learning in High School
}

\author{
Muhammad Ilyas ${ }^{1, *}$, Ma'rufi $^{1}$, Fitriani $^{1}$, Agustan Syamsuddin $^{2}$ \\ ${ }^{1}$ Department of Mathematics Education, Faculty of Teacher Training and Education, Universitas Cokroaminoto Palopo, Makassar, \\ 91911, South Sulawesi, Indonesia \\ ${ }^{2}$ Magister of Elementary Education, Postgraduate Program, Universitas Muhammadiyah Makassar, Makassar, 90221, South Sulawesi, \\ Indonesia
}

Received October 6, 2020; Revised December 1, 2020; Accepted December 13, 2020

\section{Cite This Paper in the following Citation Styles}

(a): [1] Muhammad Ilyas, Ma'rufi, Fitriani, Agustan Syamsuddin, "Integration of Emotional Intelligence: Effectiveness of Cooperative-based Mathematics Learning in High School," Universal Journal of Educational Research, Vol. 8, No. 12B, pp. 8344-8350, 2020. DOI: 10.13189/ujer.2020.082639.

(b): Muhammad Ilyas, Ma'rufi, Fitriani, Agustan Syamsuddin (2020). Integration of Emotional Intelligence: Effectiveness of Cooperative-based Mathematics Learning in High School. Universal Journal of Educational Research, 8(12B), 8344-8350. DOI: 10.13189/ujer.2020.082639.

Copyright $\mathrm{C} 2020$ by authors, all rights reserved. Authors agree that this article remains permanently open access under the terms of the Creative Commons Attribution License 4.0 International License

\begin{abstract}
This study investigated the effectiveness of integrating emotional intelligence into cooperative mathematics learning. This research paper is a pre-experiment using a one-shot case study design where there are no pretest and control groups in collecting data. 20 tenth-grade students from the class of MIA 1 were the participants of the study during the academic year of 2018/2019. Research instruments used to collect data were questionnaires of emotional intelligence and students' response related to emotional intelligence-integrated cooperative learning, an observation sheet of students' activity when emotional intelligence-integrated cooperative learning was applied in the learning process and a test of students' mathematics learning outcomes. The data obtained were quantitatively analyzed by employing descriptive statistics analysis. Findings of the study revealed that: (1) all aspect of students' activity satisfies the criteria of ideal time where the activeness of students appear in the activity of readiness to receive explanations related to subject matter, activeness in discussions both in groups and in the class, the activeness of students in answering teachers' questions and solving mathematics problem; (2) students' response is in the positive category with the average score of 78,80 where students find it easy to understand the teaching material and are motivated to take part in the learning process because students feel
\end{abstract}

challenged by solving math problems that are trained when the learning process takes place; (3) the average of students' mathematics learning outcome with the score of 78,67 passed the minimum standard of 75 ; and (4) $85 \%$ students had a score which was more than the minimum passing criteria. From the 4 aspects described, it can be argued that cooperative-based mathematics learning by integrating students' emotional intelligence can improve learning activities for both students and teachers and improve students' mathematics learning outcomes.

Keywords Cooperative Learning, Emotional Intelligence, Mathematics Learning

\section{Introduction}

Mathematics has fundamental roles in our daily life. Its application is inseparable from people's activities, for example, in business, agriculture, building construction, technology development, and other fields. Additionally, it also contributes to the development of other sciences. Therefore, mastery of mathematics in early age is necessary.

Due to the abstract and hierarchical natures of 
mathematics, however, the discipline still becomes a frightening specter for students in Indonesia. It is evident from the result of PISA (Programme for International Student Assessment) 2018, where Indonesia students' scores ranked 67 out of 73 participating countries with a score of 379 [1]. Their low scores were the result of teachers' tendency to implement teacher-centered learning, where students act only as a listener. This leads to less meaningful and interesting instruction for them.

Various ways could be employed to enhance students' mathematics skills, and one of them is implementing student-centered learning [2]. This learning allows students to discuss and construct their knowledge on their own. It does not only result in a better understanding of the topic taught, but it also becomes a meaningful mathematics lesson for them where students can relate new information obtained during the learning process with relevant concepts contained in students' cognitive structures so that students can construct new knowledge or create meaning as a result of thinking and interacting in a social context. One of the options in student-centered instructions is the cooperative model, which is suited for most of the subjects in the school curriculum, including mathematics [3].

Cooperative learning divided students into small heterogeneous groups to provide the opportunity to exchange ideas in solving the problems given. The small groups consisting of 4-6 students enable the students to collaborate, discuss, interact, solve problems, and fulfill their obligation with their peers to achieve common goals $[4,5]$.

There are six phases of cooperative learning [6]. It started with the teachers stating the learning objectives and motivating the students. The teachers then present the information or material related to the topic of the lesson to the students. After the material presentation, students were organized into their groups, and then the teacher guides and facilitates the groups to study and do their task. Next, evaluation is carried out by assessing their knowledge about the learning materials or asking several groups of students to present their works. Last but not least, the teacher gives appreciation and rewards to students for their participation in learning.

Collaboration, exchange of ideas, and peer-teaching are the goals of cooperative learning. However, several problems might arise during the learning process, such as students' participation, especially low-achieving students who tend to be passive during the learning process. Slavin [7] said that some students do not actively participate in learning and give the decision to their peers. Emotional impediment such as anxiety is one factor affecting students' passiveness. It could disturb students' mathematics performance [8]. Therefore, a solution is necessary to prevent or tackle the problem, and integrating emotional intelligence into cooperative learning could be one of the ways.
The integration of emotional intelligence into learning could minimize the main obstacles of cooperative learning. It is because emotional intelligence has a positive correlation with students' group cohesiveness [9]. Additionally, by integrating emotional intelligence in cooperative learning, students are expected to manage or control their emotions effectively. The previously passive participants can be active in their groups through the integration of emotional intelligence. According to Adinda [10], emotional intelligence allows individuals to manage their personalities to achieve their objectives and build a good relationship. It is a set of skills to recognize, identify, regulate, and monitor the feelings or emotions of self and others, to motivate ourselves, and to manage relationships with other people [11-13]. Salovey \& Mayer [13] even said that emotional intelligence could use the information regarding emotions to guides' thinking and actions.

While research on the topic of cooperative learning is prevalent, the study investigating the integration of emotional intelligence into instruction is a rarity. Some research found developing a learning media integrated with emotional intelligence [14] and another one investigated the effects of integrating it into instruction on students' attitudes toward mathematics [15].

Based on the previous explanations, it is necessary to investigate the effectiveness of the integration of emotional intelligence into cooperative-based mathematics learning in high school.

\section{Methods}

This study is pre-experimental research employing a one-shot case study where the only test is at the end of the learning process by implementing cooperative learning with integrated emotional intelligence, and there is no control group [16]. The research was conducted during the even semester in the academic year of 2018/2019. It took place in SMA Negeri 4 Palopo in the class of MIA 1, which consisted of 20 tenth-grade students. There are four lessons in the implementation of cooperative learning, which cover the topics of sine and cosine.

The research instruments used were observation sheet of students' activity, questionnaires of student's response and emotional intelligence, and a test of students' mathematics learning outcome. The data obtained were analyzed by descriptive statistics. The research design is illustrated by the following Table 1 .

Table 1. Research Design

\begin{tabular}{|c|c|}
\hline Treatment & Posttest \\
\hline $\mathrm{X}$ & $\mathrm{O}$ \\
\hline
\end{tabular}

Note:

$\mathrm{X}=$ cooperative learning integrated with emotional intelligence.

$\mathrm{O}=$ scores of students' mathematics learning outcomes 
Results from the test of mathematics' learning outcome and the questionnaire of emotional intelligence were categorized by the five-based ranking categorization, which utilizes mean and standard deviation values [17]. The ranking consisted of very high, high, average, low, and very low.

Regarding students' responses to the learning implemented, the score was classified by adapting the criteria used by Akbar [18] and Khabibah [19] from the three-based ranking to four-based ranking. They are very positive, positive, negative, and very negative.

In the study, the integration of emotional intelligence into cooperative mathematic learning is categorized as effective if it meets three of four criteria. The first criterion is that $85 \%$ of the students have to achieve the score of classical completeness (at least 75), while the second one is that their average test score must pass the minimum mastery criteria (75). As for the third criterion, the average of students' response to the learning implemented is categorized at least as positive. Lastly, five out of the seven aspects of students' activity observed are fulfilled.

\section{Results and Discussion}

\subsection{Results}

Before the implementation of cooperative learning integrated with emotional intelligence, a questionnaire of emotional intelligence was administered to the students to group them based on their level of emotional intelligence. The result of the classification is presented by the following Table 2 .

Table 2. Frequency Distribution of Emotional Intelligence Level of Students in X MIA 1 SMA Negeri Palopo

\begin{tabular}{|c|c|c|c|}
\hline No & Category & Frequency & Percentage (\%) \\
\hline 1 & Very High & 0 & 0,00 \\
\hline 2 & High & 9 & 45,00 \\
\hline 3 & Average & 5 & 25,00 \\
\hline 4 & Low & 4 & 20,00 \\
\hline 5 & Very Low & 2 & 10,00 \\
\hline \multicolumn{2}{|c|}{ Total } & 20 & 100,00 \\
\hline
\end{tabular}

Table 2 reveals that students have different levels of emotional intelligence. Almost half (9) of students' emotional intelligence are categorized as high, and five students have an average level. As for the low and very low categories, there are 4 and 2 students, respectively. The classification was used by the teacher to divide the students into small heterogeneous groups.

Findings regarding observation on students' activity during the learning process are shown in Table 3.

Based on Table 3 and the criteria of ideal time of students' activity in learning, out of the four lessons conducted, the activity of tenth-grade students from the class of MIA 1 SMA Negeri 4 Palopo in learning meets the effectiveness criteria with all scores falling into tolerance interval.

Table 3. Students' Activity during the Cooperative Learning Integrated with Emotional Intelligence

\begin{tabular}{|c|c|c|c|c|c|c|}
\hline \multirow{2}{*}{ Observed Aspects } & \multicolumn{3}{|c|}{ Percentage of Students Activity in Learning } & \multirow{2}{*}{$\begin{array}{c}\text { Ideal Time } \\
\text { (\%) }\end{array}$} & Tolerance Interval PWI \\
\cline { 2 - 6 } & RPP I & RPP II & RPP III & RPP IV & 19 & $14 \%-24 \%$ \\
\hline $\begin{array}{c}\text { Paying attention to information and taking } \\
\text { notes as necessary }\end{array}$ & 19 & 20 & 20 & 19 & 19 & $14 \%-24 \%$ \\
\hline $\begin{array}{c}\text { Reading students' worksheets, learning } \\
\text { material, or students' textbooks. }\end{array}$ & 18 & 20 & 18 & 19 & 19 & $25 \%-35 \%$ \\
\hline Active participation in assignment & 30 & 29 & 29 & 27 & 30 & $14 \%-24 \%$ \\
\hline Active discussion with friends. & 18 & 17 & 21 & 19 & 19 & $2 \%-12 \%$ \\
\hline Asking questions to students or teachers & 7 & 7 & 6 & 8 & 7 & $2 \%-12 \%$ \\
\hline $\begin{array}{c}\text { Answering or responding to students or } \\
\text { teachers' questions }\end{array}$ & 5 & 6 & 4 & 7 & 7 & 0 \\
\hline $\begin{array}{c}\text { Irrelevant activities to the current learning } \\
\text { such as playing, sleeping, etc. }\end{array}$ & 3 & 1 & 2 & 1 & 0 & 0 \\
\hline
\end{tabular}

Note: RPP is the lesson or meeting, PWI is the percentage of time indicator 
The next observed aspect is students' response toward the integration of emotional intelligence into cooperative-based mathematics learning. The data were collected by administering a questionnaire after the instruction. Analysis results of the data of their responses are as follows.

Table 4. Frequency Distribution of Students Response to Cooperative Learning Integrated with Emotional Intelligence

\begin{tabular}{|c|c|c|c|c|}
\hline No & $\begin{array}{l}\text { Students' } \\
\text { Response }\end{array}$ & Frequency & $\begin{array}{c}\text { Percentage } \\
(\%)\end{array}$ & Category \\
\hline 1 & $81,25<x \leq 100$ & 6 & 30,00 & $\begin{array}{c}\text { Very } \\
\text { Positive }\end{array}$ \\
\hline 2 & $61,25<x \leq 81,25$ & 14 & 70,00 & Positive \\
\hline 3 & $43,75<x \leq 61,25$ & 0 & 0,00 & Negative \\
\hline 4 & $0 \leq x \leq 43,75$ & 0 & 0,00 & $\begin{array}{c}\text { Very } \\
\text { Negative }\end{array}$ \\
\hline & Total & 20 & 100 & \\
\hline & Average & \multicolumn{2}{|c|}{78,80} & Positive \\
\hline
\end{tabular}

Table 4 shows that out of 20 students from X MIA 1, there were six students $(30,00 \%)$ and 14 students who give a very positive and positive response toward the implementation of cooperative learning integrated with emotional intelligence, respectively. The average is in the category of positive with a score of 78,80 , which satisfies the criteria of effectiveness.

The third aspect observed is students' mathematics learning outcome. A result of descriptive statistical analysis is revealed by the following Table 5 .

Table 5. Descriptive Statistics of Students' Learning Outcome After the Integration of Emotional Intelligence into Cooperative Learning

\begin{tabular}{|c|c|}
\hline \multirow{2}{*}{ Statistics } & Statistical Value \\
\cline { 2 - 2 } & Posttest \\
\hline Sample Size & 20 \\
\hline Mean & 78,67 \\
\hline Range & 53,33 \\
\hline Minimum Value & 43,33 \\
\hline Median & 80,00 \\
\hline Maximum Value & 96,67 \\
\hline Ideal Score & 100 \\
\hline
\end{tabular}

Based on Table 5, the mean score of students' learning outcomes after the implementation of cooperative learning is 78,67 , with the highest score and lowest score being 96,67 and 43,33, respectively. The score meets the effectiveness criteria, where the score has to be at least 75 .

In a frequency distribution, the score of the tenth-grade students of MIA 1 SMA Negeri 4 Palopo is classified into five categories. The classification is presented by the following Table 6 .
Table 6. Frequency Distribution of Students' Mathematics Learning Outcome after The Implementation of Cooperative Learning Integrated with Emotional Intelligence

\begin{tabular}{|c|c|c|c|}
\hline Score & Category & Frequency & $\begin{array}{c}\text { Percentage } \\
(\mathbf{\%})\end{array}$ \\
\hline $92 \leq \bar{x} \leq 100$ & Very High & 2 & 10 \\
\hline $83 \leq \bar{x}<92$ & High & 5 & 25 \\
\hline $75 \leq \bar{x}<83$ & Average & 10 & 50 \\
\hline $66 \leq \bar{x}<75$ & Low & 1 & 5 \\
\hline $0 \leq \bar{x}<66$ & Very Low & 2 & 10 \\
\hline Total & 20 & 100 \\
\hline \multicolumn{2}{|r|}{ Passed } & 17 & 85 \\
\hline \multicolumn{2}{|r|}{ Failed } & 3 & 15 \\
\hline
\end{tabular}

Table 6 revealed that out of 20 students, 17 of them (85\%) achieved the score, which passed the minimum mastery criteria. In classical completeness, their learning outcome after the implementation of cooperative learning satisfies the effectiveness criteria.

Based on the analysis result of activity, response, and learning outcome of tenth-grade students from the class $X$ MIA 1 SMA Negeri 4 Palopo, it can be concluded that the integration of emotional intelligence in cooperative learning is implemented effectively.

\subsection{Discussions}

Integrating emotional intelligence into cooperative-based mathematics learning is effective to improve learning activities and mathematics learning outcomes for class $\mathrm{x}$ high school students in Palopo. It is evident in the activities, responses, and learning outcomes of the students who meet the predetermined criteria. Firstly, in terms of activity during the learning process, out of the seven aspects observed in all four lessons, all aspects observed meets the ideal time. Secondly, the score of 78,80 in their response means that they responded positively toward the learning. Lastly, their average test score of 78,67 passed the minimum mastery criteria of 75, and in terms of classical completeness, 17 (85\%) students' score meets the minimum score.

This indicates that applying a cooperative learning model integrating emotional intelligence can create an effective mathematics learning process. This is in accordance with the results of research by Syam, Akib and Syamsuddin [20] which state that the application of cooperative learning is effective in improving student mathematics learning outcomes. In addition, the positive response given by students with the application of the cooperative learning model by integrating students' emotional intelligence gives an idea that students are motivated to take part in learning. The same thing was stated by Bakri, Syamsuddin and Babo [21] that cooperative learning can increase student motivation in learning mathematics. 
Moreover, several researchers reported similar findings where cooperative learning could enhance and have a positive impact on students' mathematics' learning outcome [22-29]. Furthermore, research by Syawahid \& Retnawati [30] found that in the development of a learning media that integrate emotional intelligence into a collaborative setting, there were $80 \%$ of students who passed the minimum passing criteria. It supports the statement that including emotional quotient into the learning process could enhance students' skills [31]. Hossain et al. [32] even said that all the research findings of cooperative learning provide insights on how the instruction is suited to improve students' mathematics achievement.

Many studies also investigated the impact of cooperative learning on students' activity and response. Several studies found that it enhances students' activeness $[22 ; 25 ; 26 ; 33 ; 34]$. The same goes for the response of the method used. Some researchers suggested that there were positive responses to the implementation of cooperative-based mathematics learning [33;25].

Improvement in students' activity, response, and learning outcome is possible due to the learning that allows students with the high skill to motivate their friends to be active in their group. Therefore, processes of exchange of ideas and collaboration to solve the problem happened. Moreover, by integrating emotional intelligence, students are expected to: (1) form synergy in their teamwork; (2) endure failures; (3) achieve common goals; (4) manage their emotions and those of others; and (5) build and keep their cooperative relationship and interaction in the learning process [35-36].

By paying attention to some of the findings above, it can be argued that cooperative learning that integrates emotional intelligence gives students the opportunity to come up with all their ideas when discussing with a group of friends and trying to solve the problems presented in their own way. This is in accordance with the opinion of Chatib [37] that the application of the concept of emotional intelligence in learning helps students who have difficulty learning and proves that all students are smart with their own learning methods. Thus, learning will be meaningful for students if the learning methods and materials presented are related to their experiences, interests, and potential [38-39].

Therefore, teachers must be able and creative in preparing a student-centered learning process so that it will be easier to understand the material if the teacher designs learning according to the variety of intelligence they have [40]. If students have a good concept understanding, students can confidently express their opinions in solving problems related to their learning material both verbally and nonverbally and it will increase students' mathematics learning outcomes. The use of cooperative learning approaches by integrating emotional intelligence theory makes students more responsible, cooperative and disciplined as well as enabling students to show and express what they have learned [41]. In addition, teachers can accommodate the differences that exist in students considering that the students they face have different characters both in terms of intelligence and in terms of student behavior. This is in accordance with the statement of Gardner [42] that the learning styles of students are reflected in the tendency of their intelligence.

Therefore, the teacher must be able to create a comfortable learning atmosphere namely a learning atmosphere that can eliminate student boredom due to various problems experienced by students when the learning process takes place [43]. In addition, students do not feel tense when students convey ideas or opinions related to material discussed in class. Thus, students can understand the teaching material delivered by the teacher and arouse students' motivation to learn mathematics. As a consequence, students can easily accept and absorb the material presented which has an impact on improving student mathematics learning outcomes, of course by paying attention to aspects of students' emotional intelligence and the learning methods applied in the classroom.

\section{Conclusions}

To conclude, the implementation of cooperative learning integrated with emotional intelligence is effective in mathematics learning because it meets the four criteria of effectiveness. All aspect of students' activity satisfies the ideal time, and their average response is in a positive category with a score of 78,80. Next, the average of their learning outcome is 78,67, which is more than the minimum passing criteria (75). As for the classical completeness, $17(85 \%)$ students' score is higher than the minimum score of 75 .

In addition, the application of the student's emotional intelligence integrated cooperative learning model provides opportunities for students to develop the competencies that students have both individually and in groups. Where this learning model provides opportunities for students to learn to understand the material presented by the teacher with the characteristics and learning styles adopted by the students. Thus, students will be trained to be responsible and disciplined in studying and mastering the material presented by the teacher in the classroom.

\section{Acknowledgements}

We would like to express our gratitude to the students of SMA Negeri 4 Palopo, South Sulawesi who were involved in data collection for this study who were willing to spend their time so that this research can be carried out well. 


\section{REFERENCES}

[1] OECD. PISA 2018 Results (Volume I): What Students Know and Can Do. OECD Publishing. https://doi.org/10.1787/5f07c754-en, 2019.

[2] Syamsuddin, A. The impact of implementing of INSTAD model toward student's mathematics learning outcome for 5th grade elementary school students. Journal of Physics: Conference Series, Vol. 1318, No. 1, 012021(1-7). 2019.

[3] Tarim, K., \& Akdeniz, F. The Effects of Cooperative Learning on Turkish Elementary Students' Mathematics Achievement and Attitude Towards Mathematics Using TAI and STAD Methods. Educational Studies in Mathematics, Vol. 67, No. 1, 77-91, 2008.https://doi.org/10.1007/s10649 $-007-9088-y$.

[4] Jaelani, A. Pembelajaran Kooperatif, Sebagai Salah Satu Model Pembelajaran Di Madrasah Ibtidaiyya (Mi). Al Ibtida: Jurnal Pendidikan Guru MI, Vol. 2, No. 1, 1-16, 2015

[5] Purnomo, Y. W. Keefektifan Model Penemuan Terbimbing dan Cooperative Learning pada Pembelajaran Matematika. Jurnal Kependidikan: Penelitian Inovasi Pembelajaran, Vol. 41, No. 1, 37-54, 2011.

[6] Arends, R. Learning to Teach (9th ed). New York: McGraw-Hill, 2012.

[7] Slavin, R.E. Cooperative Learning. London: Allymand Bacon, 2005.

[8] Maloney, E. A., Schaeffer, M. W., \& Beilock, S. L. Mathematics Anxiety and Stereotype Threat: Shared Mechanisms, Negative Consequences, and Promising Interventions. Research in Mathematics Education, Vol. 15, No. 2, 115-128, 2013. https://doi.org/10.1080/14794802.20 13.797744

[9] Moore, A., \& Mamiseishvili, K. Examining the Relationship Between Emotional Intelligence and Group Cohesion. Journal of Education for Business, Vol. 87, No. 5, 296-302, 2012. https://doi.org/10.1080/08832323.2011.623197.

[10] Adinda, A. Kecerdasan Emosional Dalam Pembelajaran Matematika. Logaritma: Jurnal Ilmu-ilmu Pendidikan dan Sains, Vol. 4, No. 02, 117-131, 2016.

[11] Ilyas, M. Pembelajaran Matematika Berbasis Karakter Dengan Melibatkan Kecerdasan Emosional Mahasiswa. Prosiding Seminar Nasional Universitas Cokroaminoto Palopo, Vol. 1, No. 1, 47-54, 2014.

[12] Mayer, J. D., \& Salovey, P. The intelligence of emotional intelligence. Intelligence, Vol. 17, No. 4, 433-442, 1993. https://doi.org/10.1016/0160-2896(93)90010-3

[13] Salovey, P., \& Mayer, J. D. Emotional Intelligence. Imagination, Cognition, and Personality, Vol. 9, No. 3, 185-211, 1990. https://doi.org/10.2190/DUGG-P24E-52W $\mathrm{K}-6 \mathrm{CDG}$

[14] Syawahid, M., \& Retnawati, H. Pengembangan Perangkat Pembelajaran Matematika Terintegrasi dengan Pengembangan Kecerdasan Emosional dan Spiritual. Jurnal Riset Pendidikan Matematika, Vol. 1, No. 1, 12-21, 2014.
[15] Salleh, N. binti M., \& Othman, I. bin. The Effects of Integrating Emotional Intelligence on Students' Attitudes toward Mathematics. International Journal of Asian Social Science, Vol. 4, No. 9, 966-976, 2014.

[16] Fraenkel, J. R., Wallen, N. E., Hyun, H. H. How to design and evaluate research In education (8th ed.). New York: Mc Graw Hill; 2012.

[17] Slameto. Belajar dan Faktor-faktor yang Mempengaruhinya . Jakarata: PT Bina Aksara, 2010.

[18] Ariyawati, P. A. M., Waluyo, J., \& Prihatin, J. Analisis Respon Siswa terhadap Model Pairs, Investigation and Communication (PIC) dalam Pembelajaran IPA. Jurnal Pembelajaran dan Pendidikan Sains, Vol. 2, No. 1, 9-15, 2017.

[19] Hasdah, H., Syamsuddin, A \& Idawati. Testing the Validity of a Problem Solving-Based Students' Worksheet on Space Material for 5 th Grade Elementary School Students. Journal of Critical Reviews, Vol. 7. No. 9, 1248-1250, 2020.

[20] Syam, A. P., Akib, I., Syamsuddin, A. The Application of Cooperative Learning Model of Team Assisted Individualization (TAI) Based Manipulative Media on Topics "Shape" of Class VI Elementary School of Tombolok Gowa. Daya Matematis: Jurnal Inovasi Pendidikan Matematika, Vol. 7, No. 3, 317-327, 2020.

[21] Bakri, H., Syamsuddin, A., \& Babo, R. Applying The Aptitude Treatment Interaction (ATI) Learning Model In Mathematics Learning To Improve Mathematical Concept Understanding Of 5th Grade Of Elementary School Students. Journal of Critical Reviews, Vol. 7, No. 7, 55-58, 2020.

[22] Artut, P. D., \& Bal, A. P. Learning Implementations about Cooperative Learning Method: A Case Study in Turkey. International Journal of Progressive Education, Vol. 14, No. 6, 168-176, 2018. https://doi.org/10.29329/ijpe.2018.179.13

[23] Capar, G., \& Tarim, K. Efficacy of the Cooperative Learning Method on Mathematics Achievement and Attitude: A Meta-Analysis Research. Educational Sciences: Theory \& Practice, 15(2), 553-559, 2015. https://doi.org/10.12738/est p.2015.2.2098.

[24] Dees, R. L. The Role of Cooperative Learning in Increasing Problem-Solving Ability in a College Remedial Course. Journal for Research in Mathematics Education, Vol. 22, No. 5, 409, 1991.. https://doi.org/10.2307/749188.

[25] Rhamayanti, Y. Peningkatan Hasil Belajar Matematika dan Respon Siswa Melalui Pembelajaran Kooperatif Tipe STAD dengan Metode Penemuan Terbimbing. Edumatika Jurnal Riset Pendidikan Matematika, Vol. 2, No. 1, 29-39, 2019.

[26] Sugiawan, R., Nurhanurawati, N., \& Coesamin, M. Meningkatkan Aktivitas dan Hasil Belajar Matematika Melalui Pembelajaran Kooperatif Tipe NHT. Jurnal Pendidikan Matematika UNILA, Vol. 2, No. 3, 2014.

[27] Tarim, K., \& Akdeniz, F. The Effects of Cooperative Learning on Turkish Elementary Students' Mathematics Achievement and Attitude Towards Mathematics Using TAI and STAD Methods. Educational Studies in Mathematics, Vol. 67, No. 1, 77-91, 2008. https://doi.org/10.1007/s10649 $-007-9088-y$

[28] Turgut, S., \& Turgut, İ. G. The Effects of Cooperative 
Learning on Mathematics Achievement in Turkey: A Meta-Analysis Study. International Journal of Instruction, Vol. 11, No. 3, 663-680, 2018. https://doi.org/10.12973/iji. 2018.11345a.

[29] Yalçin, K., \& Hasan, A. (2018). The Effect of Cooperative Learning on the Academic Achievement and Attitude of Students in Mathematics Class. Educational Research and Reviews, Vol. 13, No. 21, 712-722, 2018. https://doi.org/10.5897/ERR2018.3636.

[30] Syawahid, M., \& Retnawati, H. Pengembangan Perangkat Pembelajaran Matematika Terintegrasi dengan Pengembangan Kecerdasan Emosional dan Spiritual. Jurnal Riset Pendidikan Matematika, Vol. 1, No. 1, 12-21, 2014.

[31] Romero-Ternero, M. C. Can Cooperative Learning Promote Emotional Intelligence in Our Students? 2013 7th IEEE International Conference on E-Learning in Industrial Electronics (ICELIE), 60-65, 2013.https://doi.org/10.1109/ ICELIE.2013.6701273

[32] Hossain, M. A., Tarmizi, R. A., \& Ayub, A. F. M. Collaborative and Cooperative Learning in Malaysian Mathematics Education. Indonesian Mathematical Society Journal on Mathematics Education, Vol. 3, No. 2, 103-114, 2012.

[33] Leikin, R., \& Zaslavsky, O. Facilitating Student Interactions in Mathematics in a Cooperative Learning Setting. Journal for Research in Mathematics Education, Vol. 28, No. 3, 331-354, 1997. https://doi.org/10.5951/jresematheduc.28.3. 0331

[34] Mufidah, L., Effendi, D., \& Purwanti, T. T. Penerapan Model Pembelajaran Kooperatif Tipe TPS untuk Meningkatkan Aktivitas Belajar Siswa pada Pokok Bahasan Matriks. Jurnal Pendidikan Matematika STKIP PGRI Sidoarjo, Vol. 1, No. 1, 117-125 2013.
[35] Ilyas, M., Ma'rufi, M., Fitriani, F., \& Salwah, S. Analysis of senior high school students' emotional intelligence in cooperative based mathematics learning. In Journal of Physics: Conference Series, Vol. 1088, No. 1, p. 012082. IOP Publishing, 2018.

[36] Goleman, D. Emotional Intelligence. Jakarta: PT Gramedia Pustaka Utama, 2000.

[37] Chatib, M. Semua Anak Bintang: Menggali Kecerdasan dan Bakat Terpendam dengan Multiple Intelegences Research. Bandung: Kaifa. 2017.

[38] Djamarah, S. B., \& Zain, A. Strategi Belajar Mengajar. Jakarta: Rineka Cipta. 2006.

[39] Chatib, M. Sekolahnya Manusia: Sekolah Berbasis Multiple Intelligences di Indonesia. Bandung: Kaifa, 2009.

[40] Mirda, T. A., Adlim, A., \& Mursal, M. Pengembangan Lembar Kerja Peserta Didik Berbasis Multiple Intelligences Pada Materi Gerak Harmonik. Jurnal Pendidikan Sains Indonesia, Vol. 5, No. 2, 95-103, 2018. https://doi.org/10.2 4815/jpsi.v5i2.9823

[41] Leonardo, R. R. Multiple Intelligences Teaching and Assessment: Its Influences on Filipino College Students. Mathematics Performance and Learning Experiences, Vol. 5, No. 5, 31-36, 2015.

[42] Gardner, H. Frames of Mind: The Theory Of Multiple Intelligences. Basic Books, 1983.

[43] Aisyah, N., S., Akib, I., \& Syamsuddin, A. Identifying The Influence Of Anxiety And Self-Reliance In Learning Towards Mathematics Learning Performance Of Elementary School's Students Grade V. International Journal of Scientific \& Technology Research, Vol. 8, No. 12, 3436-3440, 2020 